Discussion

Papers

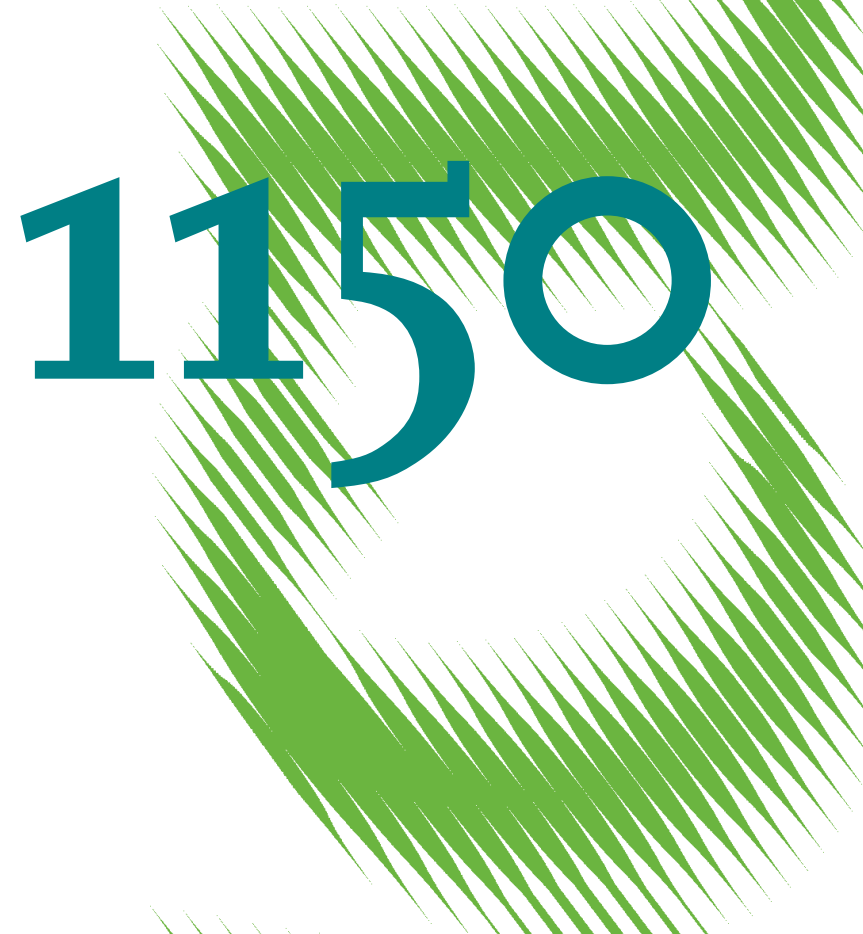

Industry-Specific Knowledge Spurs Productivity

An Application of Panel Cointegration 
Opinions expressed in this paper are those of the author(s) and do not necessarily reflect views of the institute.

IMPRESSUM

(C) DIW Berlin, 2011

DIW Berlin

German Institute for Economic Research

Mohrenstr. 58

10117 Berlin

Tel. $+49(30) 89789-0$

Fax +49 (30) $89789-200$

http://www.diw.de

ISSN print edition $1433-0210$

ISSN electronic edition 1619-4535

Papers can be downloaded free of charge from the DIW Berlin website:

http://www.diw.de/discussionpapers

Discussion Papers of DIW Berlin are indexed in RePEc and SSRN:

http://ideas.repec.org/s/diw/diwwpp.html

http://www.ssrn.com/link/DIW-Berlin-German-Inst-Econ-Res.html 


\title{
Industry-Specific Knowledge Spurs Productivity: \\ An Application of Panel Cointegration
}

\author{
Petra Zloczysti \\ DIW Berlin - German Institute for Economic Research \& Freie Universität Berlin \\ pzloczysti@diw.de
}

August 2011

\begin{abstract}
Using data for 14 OECD countries and 13 sectors for the period 1985-2004, this paper analyzes the significance of the linkage between channels of international knowledge spillovers and total factor productivity. We distinguish between domestic and international intra- and inter-sectoral spillover sources. Patent applications are exploited to estimate the contribution of technology transfer to industrial productivity. To account for technological distance, we weight foreign knowledge by bilateral technological proximity. By adopting estimation methods reflecting recent developments in the treatment of non-stationary panel data econometrics, we find that industry-specific knowledge both nationally and internationally mainly drives productivity in the respective sector.
\end{abstract}

Keywords: Knowledge Spillover, Total Factor Productivity, Manufacturing, Panel Cointegration

JEL Classification: C23, L60, O30, O40 



\section{Introduction}

The transmission of technological knowledge to stimulate growth and productivity is an issue that is widely discussed in modern economics. The endogenous growth theory posits that technological progress is determined by innovative activity which in turn responds to economic incentives (e.g. [52], [1]). In this view, efforts devoted to R\&D together with existing expertise on technologies and processes determine a country's productivity level. Empiricists argue that the seminal contribution of Coe and Helpman [12] and numerous subsequent studies (e.g. [37], [13]) confirm the importance of technology spillovers for a country's total factor productivity (TFP). In this view, a country's productivity is enhanced by its own R\&D efforts first and then by foreign R\&D capital. ${ }^{1}$

Unlike country-level studies, there has been little investigation of the role and channels of spillovers across sectors (e.g. [32], [41]). Nevertheless, the pattern of productivity of countries and industries has undergone remarkable changes by either transferring knowledge indirectly through trading intermediate goods, or directly through exchanging tacit knowledge at the micro level [58]. Being integrated into flows of knowledge tends to equalize the differences in productivity domestically across industries and internationally between countries whereas being cut off tends to aggravate existing differences and increase the danger of lagging behind. Analyzing the importance of knowledge spilling over within and between industries is relevant because it enables policy-makers to shape and refine appropriate policies. This paper contributes to the discussion by stressing the importance of inter- and intra-industry knowledge spillovers in explaining productivity growth.

The literature on the effects of spillovers on industrial TFP differentiates between domestic and foreign spillovers and between intra- and inter-sectoral sources [41], _the four channels over which knowledge can transcend boundaries and affect productivity (e.g. [6]). Recent work can be traced to Keller [32] who analyzes whether knowledge transfers indirectly affect TFP via the international trade of goods. The

\footnotetext{
${ }^{1}$ Excellent surveys of the literature on R\&D spillovers are [45], [11] and [33].
} 
notion of trade as an influential factor was introduced by Coe and Helpman [12], who show that R\&D spillovers take place through imported goods. Among others, Lichtenberg and van Pottelsberghe [40] generally confirm their findings, but point to the methodological concerns which have given rise to an alternative specification for foreign knowledge that is still based on trade flows. These measures are used in subsequent work on the analysis of technology transfer (e.g. [37], [38]) and, more recently, the contribution of institutional variables [13] and human capital (e.g. [14], [2]) to TFP.

In general, empirical studies on the role of knowledge spillovers for TFP growth mainly rely on two features: 1 . the approximation of existing knowledge by R\&D capital stocks; and 2. a weighting of foreign knowledge by the trading patterns of countries. Both aspects have been discussed critically. Griliches [20] suggests distinguishing between rent spillovers and pure knowledge spillovers. In his view, rent spillovers occur when an increase in the quality of intermediate goods is not accompanied by a proportionate increase in prices which causes knowledge to spill over from the supplier to the producer of the final good and results in efficiency gains. Hence, rent spillovers are assumed to depend on international trade flows. Studies using import shares for weighting purposes therefore focus on rent spillovers originating from economic transactions (e.g. [41], [32]).

On the contrary, pure knowledge spillovers are difficult to quantify since they are assumed to be mainly tacit [15]. However, it is not easy to separate pure knowledge from rent spillovers in theory and empirics [44]. Verspagen [59] and Los and Verspagen [42] exploit patent data to study this type of spillover and use a measure of technological proximity suggested by Jaffe [27] to quantify the ease of knowledge circulating between countries. Eaton and Kortum [16] argue that patent data can be interpreted as a more direct indicator of innovative activity compared to R\&D because the data contain information about the origins of technologies and are legally related to invention and novelty. Using patents, Madsen [43] examines the impact of knowledge stocks on TFP for historical data and finds that international patenting has a substantial effect on TFP growth and convergence. To our knowledge, Lach [35] has conducted the only patent-based analysis on the industry level to evaluate the impact of the patent 
stock on productivity growth in American manufacturing. He finds an output elasticity of knowledge of around 0.3 , which is remarkably high compared to those found for R\&D.

Related to the measure of innovative activity - R\&D or patents - is the choice of a weighting scheme for foreign spillover sources. As mentioned above, focusing on trade structures is related to the analysis of rent spillovers. Studies on pure knowledge spillovers therefore apply the concept of technological proximity between countries, industries or firms - depending on the level of observation - to measure the technological distance from the spillover-receiver. Los and Verspagen [42] apply this methodology to study the effect of the two types of spillovers in U.S. manufacturing. ${ }^{2} \quad$ An update by Lee [36] casts further doubt on the importance of trade for the diffusion of knowledge by showing that the impact of import shares nearly vanishes when controlling for real knowledge spillovers.

To our knowledge, this paper is the first to study the channels of pure knowledge transfer on the industry level using patent data and applying the concept of technological proximity to ensure focusing on direct knowledge spillovers. We close the existing research gap by providing empirical evidence on the productivity and innovation linkage via an analysis of patent data for 14 OECD countries and 13 industries. We suggest that using patents as an indicator of innovative output highlights the robustness of previous results considering the different approaches of capturing knowledge.

Previous literature has partly neglected the time-series properties of the underlying variables. Referring to the work of Coe and Helpman [12], Kao et al. [30] emphasize the need to account for non-stationarity of data and suggest applying dynamic linear regression analysis. We conduct various panel unit root and recently developed panel cointegration tests to investigate the time series properties of our variables. Estimations are presented for ordinary (OLS) and dynamic ordinary least squares (DOLS). Our results indicate that domestic and international intra-industry knowledge 
spillovers have significant impacts on TFP growth and that technologies originating from other sectors do not affect productivity. Our results indicate that intra-industry knowledge spillovers, domestically and internationally, have a considerable effect on TFP growth. Technologies originating from other sectors are not found to affect productivity.

The paper is organized as follows: Section 2 sketches the theoretical background and Section 3 introduces data sources and the construction of variables. Section 4 presents the econometric techniques and discusses the estimation results. Section 5 presents our conclusions.

\section{Theoretical Background}

The idea that externalities like knowledge spillovers affect productivity has an even longer history in the economic literature than the endogenous growth theory. In the early contributions, the main source of externalities is assumed to be "learning by doing" as suggested by Arrow [3]. The model still being used in empirical applications nowadays goes back to Griliches [20]. It transfers the early approaches on knowledge externalities to the field of R\&D.

Generalizing the initial model to the country level, we assume that a country's output in industry $\mathrm{j}$ is given by the following Cobb-Douglas style production function:

$$
\mathrm{Y}_{\mathrm{j}}=\mathrm{AS}_{\mathrm{j}}^{\delta} \mathrm{S}_{0}^{\gamma} \mathrm{L}_{\mathrm{j}}^{\alpha} \mathrm{K}_{\mathrm{j}}^{1-\alpha}, \quad 0<\alpha<1,
$$

with $\mathrm{L}_{\mathrm{j}}$ denoting manpower, $\mathrm{K}_{\mathrm{j}}$ representing physical capital and $\mathrm{A}$ being a positive constant. Production is linked to technological capital via $S$, where $S_{j}$ is the knowledge capital being specific to industry j. $\mathrm{S}_{\mathrm{o}}$ stands for the state of aggregate technological knowledge outside the industry. The two major assumptions in this model are: 1. constant returns to scale with respect to physical capital, and 2. labor and common factor prices to all firms within a certain industry. ${ }^{3}$

\footnotetext{
2 The patent-based measure of technological proximity is also combined with R\&D data to stress the role of pure knowledge transfers: e.g. [22] uses this measure to study the impact of domestic R\&D by sources of funding.

${ }^{3}$ Relaxing these assumptions leads to the inclusion of further terms, which reflect e.g., how productivity alters as the firm structure of an industry changes.
} 
An aggregation of inputs to a conventional total input index

$$
\mathrm{X}_{\mathrm{j}}=\mathrm{L}_{\mathrm{j}}^{\alpha} \mathrm{K}_{\mathrm{j}}^{1-\alpha}
$$

leads to the common definition of TFP

$$
\operatorname{TFP}_{j}=\frac{Y_{j}}{X_{j}} .4
$$

Given the production function as specified above leads to the following linear equation relating productivity to knowledge inside and outside the industry:

$$
\ln \left(\mathrm{TFP}_{\mathrm{j}}\right)=\ln (\mathrm{A})+\delta \ln \left(\mathrm{S}_{\mathrm{j}}\right)+\gamma \ln \left(\mathrm{S}_{0}\right) \text {. }
$$

To adapt this theoretical framework to a multi-country and multi-industry setting, we follow previous studies and further distinguish between domestic and international knowledge to specify $S_{0}$. Therefore, we assume that the production of industry $\mathrm{j}$ in country i depends on knowledge within and outside the industry as well as on international knowledge inside and outside sector $\mathrm{j}$ :

$$
\ln \left(\mathrm{TFP}_{\mathrm{ij}}\right)=\ln (\mathrm{A})+\delta\left(\mathrm{S}_{\mathrm{ij}}^{\mathrm{D}}\right)+\gamma\left[\ln \left(\mathrm{S}_{\mathrm{i}-\mathrm{j}}^{\mathrm{D}}\right)+\ln \left(\mathrm{S}_{\mathrm{ij}}^{\mathrm{F}}\right)+\ln \left(\mathrm{S}_{\mathrm{i}-\mathrm{j}}^{\mathrm{F}}\right)\right]
$$

We thereby allow for four channels of spillovers: two intra-sectoral, national $S_{i j}^{D}$ and international $S_{i j}^{F}$, and two inter-sectoral sources, $S_{i-j}^{D}$ and international $S_{i-j}^{F}$.

Theoretically, the impact of inter-sectoral spillovers could also be estimated by treating all sectors in the sample as separate regressors in the estimation equation. However, sector-specific knowledge pools reveal a high degree of correlation leading to the problem of collinearity. Griliches [21] mentions this empirical issue and points to the problem of "wrong" signs and insignificant test statistics. Other authors choose only a few. However, this still incurs the danger of omitted variable bias and therefore is sometimes combined with certain restrictions (e.g. [5]). We circumvent the problem by separating spillovers only into intra- and inter-sectoral components.

\footnotetext{
${ }^{4}$ In the absence of measurement error.
} 


\section{Data and Variables}

The econometric analysis is based on a balanced panel of 14 OECD countries ${ }^{5}$ and 13 industries from the manufacturing sector over the period 1985-2004.6 The analysis begins with the construction of variables for TFP and knowledge spillovers.

\subsection{Total Factor Productivity}

Calculating the measure of TFP derives from a homogenous Cobb-Douglas technology using the EU KLEMS ${ }^{7}$ growth and productivity accounts which combine an extended historical time series with a detailed breakdown at the industry level. ${ }^{8}$ TFP in the industry sector $\mathrm{j}$ for country $\mathrm{i}$ is defined as:

$$
\operatorname{TFP}_{i j}=\frac{Y_{i j}}{L_{i j}^{\alpha} K_{i j}^{1-\alpha}}
$$

where $Y_{i j}$ indicates value-added in the respective industry, $K_{i j}$ denotes physical capital input and $\mathrm{L}_{\mathrm{ij}}$ labor service inputs in terms of hours worked. TFP in this context is modeled as the ratio of an output quantity index of value added to the weighted sum of quantity indices of capital and labor inputs where $\alpha$, the average annual share of labor compensation in value added, serves as weight. ${ }^{9}$ All variables are indexed such that 1995 equals 100 .

TFP reveals an upward trend over the period 1985-2004, even though substantial variation is present across countries and industries. The different sectors show remarkable differences in average productivity growth rates (Table 1), which vary between $-2.2 \%$ for coke, petroleum and nuclear fuel and $+5.8 \%$ for electrical and optical equipment.

\section{Table 1}

\footnotetext{
${ }^{5}$ Australia (AUS), Austria (AUT), Belgium (BEL), Denmark (DNK), Finland (FIN), France (FRA), Germany (GER), Italy (ITA), Japan (JPN), Netherlands (NLD), South Korea (KOR), Spain (ESP) United Kingdom (UK), United States (USA).

6 Only in the case of South Korea, one industry (Wood) must be dropped due to insufficient patenting activity.

${ }^{7}$ EU KLEMS database, March 2008, see [56] for a short overview and [57] for a detailed description of the underlying methodology.

${ }^{8}$ Most of the previous studies are based on the OECD STAN database. The advantages of the EU KLEMS database are the harmonized methodology in calculating capital stocks and the use of additional data sources to expand coverage [46].
} 
Cumulative average annual growth rates of TFP (1985-2004)

Industry description

TFP growth rate

Food products, beverages, and tobacco

0.14

Textiles, textile products, leather, and footwear

Wood, products of wood and cork

Pulp, paper, paper products, printing, and publishing

0.34

Coke, refined petroleum products, and nuclear fuel

$-2.23$

Chemicals and chemical products

Rubber and plastics products

Other nonmetallic mineral products

Basic metals and fabricated metal products

Machinery

Electrical and optical equipment

Transport equipment

Manufacturing NEC, recycling

0.47

Notes: Averages are calculated over countries. Growth rates in \%.

Source: EU KLEMS database. Own calculations.

Figures A.1-A.4 (Appendix) display the evolution of TFP in the R\&D-intensive industries chemicals and chemical products; machinery; electrical and optical equipment; and transport equipment for selected countries. We find a positive trend in all sectors, with the growth of TFP highest in electrical and optical equipment, especially in the United States and Finland. Compared to this expansive growth, the average productivity increase in machinery is moderate, with the exception of France. In chemicals and chemical products, Germany shows the largest growth when comparing the initial with the final level, whereas France exhibits relatively weak progress. Transport equipment provides a mixed picture concerning the relative positions of countries, but overall reveals an upward trend.

\subsection{Technological Proximity}

Foreign spillover pools are constructed as the sum of foreign countries' established knowledge weighted by bilateral technological distance, which is supposed to reflect the

\footnotetext{
${ }^{9}$ EU KLEMS uses Tornqvist indices for aggregation.
} 
ease of knowledge transcending boundaries. Technological proximity are calculated according to Jaffe [27], [28] who compares countries' positions in technology space. The potential to benefit from foreign $R \& D$ is affected by bilateral distance: the closer countries' profiles the more they will spur each other's research activities.

Initially, Jaffe's measure was developed to derive weights for potential spillover pools on the firm level. Subsequent studies applied it to the country level to characterize the similarity of innovative activities in countries (e.g. [37], [23]). ${ }^{10}$ There are two main assumptions: 1. all countries possess an equal ability to appropriate knowledge [28], and 2. technology can flow directly without the need of letting goods circulate [22]. This second assumption is an important distinction to the approach suggested by Coe and Helpman [12], which relies on tradable goods and therefore focuses on rent spillovers.

We first identify the areas of innovative activity across technologies using technology areas defined by Schmoch et al. [54]. ${ }^{11}$ Formally, a vector covering the shares in patenting behavior over well-defined technological fields summarizes the technological position of a country. The number of elements in the vectors equals 44 , one element for each field $\mathrm{n}$ in country $\mathrm{i}$ at time $\mathrm{t}$ :

$$
\mathrm{F}_{\mathrm{it}}=\left(\begin{array}{lll}
\mathrm{F}_{1} & \ldots & \mathrm{F}_{44}
\end{array}\right)=\left(\begin{array}{lll}
\frac{\mathrm{P}_{\mathrm{it} 1}}{\sum_{\mathrm{n}=1}^{44} \mathrm{P}_{\mathrm{itn}}} & \ldots & \frac{\mathrm{P}_{\mathrm{it} 44}}{\sum_{\mathrm{n}=1}^{44} \mathrm{P}_{\mathrm{itn}}}
\end{array}\right) .
$$

where $P_{i t n}$ is the number of patent applications filed in field $n$ and $F_{i t}$ reflects the corresponding frequency distribution.

Using the angular separation of vectors of country $i$ and $k$, the proximity measure $\mathrm{PM}_{\mathrm{ikt}}$ is derived as:

$$
P M_{i k t}=\frac{F_{i t} F_{k t}{ }^{\prime}}{\sqrt{\left(F_{i t} F_{i t}{ }^{\prime}\right)\left(F_{k t} F_{k t}{ }^{\prime}\right)}} .
$$

Intuitively, the measure is calculated as the uncentered correlation between two vectors of technological position. It is therefore bounded by 0 and 1 , with a value of 1 indicating identical technological patterns of innovative activity. A proximity of 0 implies

\footnotetext{
${ }^{10}$ An application at the industry level is [42].

11 The 44 technological fields are in Appendix A.2.
} 
orthogonal positions in technology space with no potential to benefit from each other's research activities. The technological distance is calculated for every year and thereby underlies certain dynamics. Unlike the Euclidian distance, this approach is not sensitive to the length of vectors.

Table 2 displays the average pattern of technological similarity. In terms of technological distance, the United States and the United Kingdom are quite close. Overall, Japan and South Korea exhibit the lowest proximity on average to European countries, which reflects a slightly different pattern of specialization that might reduce their ability to benefit from European technological externalities. 
Table 2

Average technological proximity (1985-2004)

\begin{tabular}{|c|c|c|c|c|c|c|c|c|c|c|c|c|c|c|}
\hline & AUS & AUT & BEL & DNK & ESP & FIN & FRA & GER & ITA & JPN & KOR & NLD & UK & USA \\
\hline AUS & 1 & & & & & & & & & & & & & \\
\hline AUT & 0.867 & 1 & & & & & & & & & & & & \\
\hline BEL & 0.841 & 0.805 & 1 & & & & & & & & & & & \\
\hline DNK & 0.912 & 0.794 & 0.828 & 1 & & & & & & & & & & \\
\hline ESP & 0.892 & 0.882 & 0.817 & 0.870 & 1 & & & & & & & & & \\
\hline FIN & 0.628 & 0.634 & 0.591 & 0.572 & 0.610 & 1 & & & & & & & & \\
\hline FRA & 0.914 & 0.899 & 0.859 & 0.833 & 0.901 & 0.718 & 1 & & & & & & & \\
\hline GER & 0.859 & 0.909 & 0.865 & 0.780 & 0.865 & 0.660 & 0.949 & 1 & & & & & & \\
\hline ITA & 0.870 & 0.930 & 0.858 & 0.825 & 0.915 & 0.625 & 0.908 & 0.937 & 1 & & & & & \\
\hline JPN & 0.741 & 0.690 & 0.744 & 0.616 & 0.673 & 0.608 & 0.846 & 0.792 & 0.715 & 1 & & & & \\
\hline KOR & 0.659 & 0.588 & 0.603 & 0.583 & 0.637 & 0.583 & 0.723 & 0.624 & 0.607 & 0.814 & 1 & & & \\
\hline NLD & 0.818 & 0.764 & 0.806 & 0.723 & 0.756 & 0.697 & 0.887 & 0.824 & 0.788 & 0.918 & 0.778 & 1 & & \\
\hline UK & 0.943 & 0.841 & 0.887 & 0.898 & 0.882 & 0.692 & 0.955 & 0.888 & 0.873 & 0.841 & 0.737 & 0.885 & 1 & \\
\hline USA & 0.899 & 0.766 & 0.866 & 0.846 & 0.801 & 0.645 & 0.908 & 0.842 & 0.810 & 0.889 & 0.754 & 0.901 & 0.962 & 1 \\
\hline
\end{tabular}

Notes: Displayed is the average proximity over years (1985-2004). 


\subsection{Knowledge Stocks}

In line with previous literature, we distinguish between intra- and inter-sectoral knowledge spillovers. The reasoning is that research carried out in other countries but within the same sector might stimulate certain local innovative activities more than those in other sectors due to the same underlying technology set. This requires the calculation of four distinct technological variables covering domestic externalities within the sector and from other sectors as well as international externalities, again inand outside the sector.

We use patent applications as measures of innovative output to approximate existing knowledge. The information on patent applications made between 1985 and 2004 is taken from the European Patent Office's Worldwide Patent Statistical Database. ${ }^{12}$ Applications are dated using the priority date.

The assignment of patents to industries covered by EUKLEMS is based on a concordance developed by Schmoch et al. [54], who use expert assessments and microdata evidence on the patent activity of firms in the manufacturing industry to link technologies to industries. The technological classes contained in the patent application are linked to technological fields and then aggregated to industries based on the NACE code. ${ }^{13}$

We construct domestic and foreign knowledge stocks to model potential pools for spillovers. The domestic knowledge stock of country $i$ originating from industry $j$ at time $\mathrm{t}$ is denoted by $S_{\mathrm{ijt}}^{\mathrm{D}}$. It is indexed such that 1995=100 and calculated using the perpetual inventory method, which depreciates knowledge at a constant rate. ${ }^{14}$ Compared to the evolution of TFP, the increase in $S_{\mathrm{ijt}}^{\mathrm{D}}$ in the R\&D-intensive industries is larger and smoother over time (Appendix Figures A.5-A.8). Especially in the chemicals and chemical products sector, we observe a uniform upward trend across all countries.

\footnotetext{
12 PATSTAT 1/2008, maintained by the European Patent Office (EPO).

${ }^{13}$ The entire concordance of International Patent Classification (IPC) classes and NACE industries is given in Appendix A.1. A patent counts for each sector covered by its IPC classes.

${ }^{14}$ We assume a depreciation rate of $15 \%$ and an initial growth rate of $20 \%$ which is common in the literature.
} 
The same holds for machinery; overall the domestic knowledge stocks rise on average by $50 \%$ between 1995 (our base year) and 2004, which is slightly less than in the chemical industry. Finland experiences a drastic knowledge increase in its electrical and optical equipment sector; the stock quadrupled in the second half of our estimation period. Finland is followed by Germany which doubles its domestic industry-specific stock. Transport equipment shows Germany and Japan in the lead while the other countries reveal a relatively lower but steady growth.

Knowledge potentially spilling over from other sectors in the economy is summarized by

$$
S_{i-j t}^{D}=\sum_{m \neq j} S_{i m t}^{D}
$$

which is simply the sum of the domestic stocks in country $\mathrm{i}$, except for industry $\mathrm{j}$. International knowledge stocks are constructed as the weighted sum over foreign knowledge stocks where bilateral technological distance serves as the weighting scheme. In the case of international intra-sectoral spillovers, i.e. within one industry, the corresponding variable is given by

$$
\mathrm{S}_{\mathrm{ijt}}^{\mathrm{F} \text { prox }}=\sum_{\mathrm{k} \neq \mathrm{i}} \mathrm{PM}_{\mathrm{ikt}} \mathrm{S}_{\mathrm{kjt}}^{\mathrm{D}} .
$$

Accordingly,

$$
\mathrm{S}_{\mathrm{i}-\mathrm{jt}}^{\mathrm{F}}{ }_{\mathrm{k} \neq \mathrm{i}} \sum_{\mathrm{m} \neq \mathrm{j}} \mathrm{PM}_{\mathrm{ikt}} \mathrm{S}_{\mathrm{kmt}}^{\mathrm{D}}
$$

defines the inter-sectoral foreign knowledge available to country $i$ and sector $j$ originating from other countries and sectors.

To further control for the impact of the weighting scheme, we derive unweighted spillover variables as follows. Let the unweighted international spillover pool be denoted by $S_{i j t}^{\mathrm{F}}$ being the sum of foreign knowledge (available to country i) produced in industry $\mathrm{j}$, and therefore representing international intra-sectoral spillovers. In the same manner, the inter-sectoral (other than sector $\mathrm{j}$ ) foreign stock available to country $\mathrm{i}$ can be derived and is denoted by $\mathrm{S}_{\mathrm{i}-\mathrm{jt}}^{\mathrm{F}}$. Again, we transform all explanatory variables into index values with base year 1995. This ensures comparability by the freedom from units of measurement and erasing the industry- or country-specific differences in levels. 
Tables 3 displays the summary statistics for the dependent and the explanatory variables used.

Table 3

Summary statistics: (1985-2004)

\begin{tabular}{|c|c|c|c|c|c|}
\hline Variable & Description & Mean & S.D. & Min & Max \\
\hline $\ln (\mathrm{TFP})$ & $\begin{array}{l}\text { Value-added based } \\
\text { TFP growth, } \\
\text { constructed as index } \\
\text { with } 1995=100\end{array}$ & 4.586 & 0.298 & -0.252 & 7.157 \\
\hline $\ln \left(S_{j}^{D}\right)$ & $\begin{array}{l}\text { Domestic stock of } \\
\text { patent applications in } \\
\text { industry j, } \\
\text { constructed as index } \\
\text { with } 1995=100\end{array}$ & 4.558 & 0.564 & 0.469 & 7.017 \\
\hline $\ln \left(S_{-j}^{D}\right)$ & $\begin{array}{l}\text { Domestic stock of } \\
\text { patent applications in } \\
\text { all industries, except } \\
\text { j, constructed as } \\
\text { index with } 1995=100\end{array}$ & 4.569 & 0.604 & 1.718 & 6.811 \\
\hline $\ln \left(S_{j}^{\text {Fprox }}\right)$ & $\begin{array}{l}\text { Foreign stock of } \\
\text { patent applications in } \\
\text { industry j, countries } \\
\text { weighted by } \\
\text { technological } \\
\text { proximity, } \\
\text { constructed as index } \\
\text { with } 1995=100\end{array}$ & 4.579 & 0.360 & 2.815 & 5.390 \\
\hline $\ln \left(S_{j}^{F}\right)$ & $\begin{array}{l}\text { Foreign stock of } \\
\text { patent applications in } \\
\text { industry j, } \\
\text { constructed as index } \\
\text { with } 1995=100\end{array}$ & 4.584 & 0.341 & 3.591 & 5.381 \\
\hline $\ln \left(S_{-j}^{F \text { prox }}\right)$ & $\begin{array}{l}\text { Foreign stock of } \\
\text { patent applications in } \\
\text { all industries, except } \\
\text { j, countries weighted } \\
\text { by technological } \\
\text { proximity, } \\
\text { constructed as index } \\
\text { with } 1995=100\end{array}$ & 4.594 & 0.383 & 3.070 & 5.262 \\
\hline $\ln \left(S_{-j}^{F}\right)$ & $\begin{array}{l}\text { Foreign stock of } \\
\text { patent applications in } \\
\text { all industries, except } \\
\text { j, constructed as } \\
\text { index with } 1995=100\end{array}$ & 4.598 & 0.367 & 3.893 & 5.231 \\
\hline
\end{tabular}




\section{Empirical Analysis}

\subsection{Estimation Model}

To estimate the effect of different channels of knowledge spillovers on productivity in a multi-country, multi-industry setting, we use the model described in Section 2:

$$
\ln \left(\mathrm{TFP}_{\mathrm{ijt}}\right)=\alpha_{\mathrm{i}}+\beta_{1}\left(\frac{S_{\mathrm{ijt}}^{\mathrm{D}}}{S_{\mathrm{ij} 1995}^{\mathrm{D}}}\right)+\beta_{2} \ln \left(\frac{S_{\mathrm{i}-\mathrm{jt}}^{\mathrm{D}}}{S_{\mathrm{i}-\mathrm{j} 1995}^{\mathrm{D}}}\right)+\beta_{3} \ln \left(\frac{S_{\mathrm{ijt}}^{\mathrm{F}}}{S_{\mathrm{ij} 1995}^{\mathrm{F}}}\right)+\beta_{4} \ln \left(\frac{S_{\mathrm{i}-\mathrm{jt}}^{\mathrm{F}}}{S_{\mathrm{i}-\mathrm{j} 1995}^{\mathrm{F}}}\right)+\mathrm{u}_{\mathrm{ijt}}
$$

with $i=1, \ldots, 14 \quad j=1, \ldots, 13 \quad t=1985, \ldots, 2004$.

We thereby allow for dissimilar coefficients of the knowledge stocks and countryspecific fixed effects $\alpha_{i}$, which cover determinants not included in our model. Note that each estimated coefficient could be interpreted as an elasticity of TFP with respect to the variable of interest. Because we cannot exclude the possibility of non-stationarity of our variables, we could face the spurious correlation problem when running regressions on this equation. Therefore, before estimating the model and interpreting the coefficients as reflecting the long-run relationship between knowledge stocks and productivity, we turn to the analysis of the stochastic properties of the underlying time series. ${ }^{15}$

\subsection{Cointegration Preliminaries}

The first step is to pre-test all variables to find whether they contain a unit root. Several procedures for testing the presence of unit roots in case of panel data have been suggested in the literature. ${ }^{16}$ All approaches try to combine the time-series with the cross-sectional dimension of the data to improve inference on unit roots and cointegration. Given this background, a persisting problem is the asymptotic behavior of the test statistics as $\mathrm{N}$ and $\mathrm{T}$ both tend to infinity.

\footnotetext{
15 Granger and Newbold [19] introduce the notion of spurious regression. Based on simulations, they show that regression analysis based on non-stationary data series produces statistically significant results that have no economic meaning except for the case of cointegration.

${ }^{16}$ Breitung and Pesaran [8] review recent developments in this field. Concerning the first generation of tests, see Banerjee [4].
} 
Table 3 presents the results for four different unit root tests: Levin et al. [39], Breitung [7], Im et al. [26] and Hadri [24]. Levin ${ }^{17}$ et al. [39] were one of the first to develop a panel unit root test, which tests the hypothesis of non-stationarity of all time series against the alternative of stationarity of all series. The hypothesis of non-stationarity cannot be rejected by the Levin et al. [39] test for all variables. Breitung [7] suggests a slightly different approach that conducts an adjustment before running the regression. Thereby, bias correction is no longer necessary. Also the Breitung [7] test cannot reject the null hypothesis that all panel members reveal a unit root. Im et al. [26] suggest a more flexible framework by allowing for heterogeneity in the autoregressive parameters. Hence, we can still hypothesize that all series are non-stationary under the null, but under the alternative only a fraction needs to be stationary. However, we find no evidence for stationary processes.

\section{Table 4}

Panel unit root tests (1985-2004)

\begin{tabular}{lcccc}
\hline Variable & $\begin{array}{c}\text { Levin, Lin and } \\
\text { Chu }\end{array}$ & Breitung & $\begin{array}{c}\text { Im, Pesaran } \\
\text { and Shin }\end{array}$ & Hadri \\
\hline $\ln (\mathrm{TFP})$ & 5.116 & 1.790 & 0.098 & $43.089^{* * *}$ \\
$\ln \left(\mathrm{S}_{\mathrm{j}}^{\mathrm{D}}\right)$ & 8.358 & 1.113 & -1.203 & $66.352^{* * *}$ \\
$\ln \left(\mathrm{S}_{-\mathrm{j}}^{\mathrm{D}}\right)$ & 31.203 & 2.898 & 5.788 & $78.012^{* * *}$ \\
$\ln \left(\mathrm{S}_{\mathrm{j}}^{\mathrm{Fprox}}\right)$ & 5.862 & 4.120 & 5.817 & $84.216^{* * *}$ \\
$\ln \left(\mathrm{S}_{\mathrm{j}}^{\mathrm{F}}\right)$ & 17.460 & 6.307 & 18.462 & $88.497^{* * *}$ \\
$\ln \left(\mathrm{S}_{-\mathrm{j}}^{\mathrm{F} \text { prox }}\right)$ & 26.315 & -1.159 & -0.838 & $73.28^{* * *}$ \\
$\ln \left(\mathrm{S}_{-\mathrm{j}}^{\mathrm{F}}\right)$ & 12.902 & 2.749 & 17.515 & $96.126^{* * *}$ \\
\hline
\end{tabular}

Notes: Significance levels of $10 \%, 5 \%$, and $1 \%$ for the one-tailed tests are indicated by *, ** and ***. The null hypothesis of a unit root is rejected if the test statistic is significant in case of Levin et al. [39], Breitung [7] and Im et al. [26]. On the contrary, Hadri [24] tests the null of stationarity. Variables are demeaned to mitigate the impact of crosssectional dependence. Lags are specified such that the Akaike information criterion is minimized.

\footnotetext{
17 The test is often referred to as the Levin and Lin test because it started circulating as a working paper in 1992. Chu joined the co-authors in the published version.
} 
If it can be argued that we are interested in showing that our variables are stationary, it might be more appropriate to test the null hypothesis of stationarity against the alternative of non-stationarity. As Hadri [24] points out, classical hypothesis testing tends to accept the null hypothesis unless the data series exhibits strong evidence for the alternative. He proposes a Lagrange multiplier-based test on the null of stationarity. We find that the hypothesis of stationarity can be rejected for all dependent and explanatory variables at the $1 \%$ level. As all tests rely on the assumption of crosssectional independence, we demean all time series when conducting the panel unit root tests to mitigate the impact of dependence being prevalent in the data as suggested by Levin et al. [39].18

Having established that all variables exhibit a unit root, i.e. are non-stationary, we next conduct a panel cointegration test to ensure that a long-term relationship exists. Note that we consider panel cointegration as the long-term relationship between our dependent and explanatory variables being present in the countries and sectors. This is in sharp distinction to the concept of cross-member cointegration where the dependent variables of panel members are cointegrated.

Methods of testing for panel cointegration are receiving more attention, especially in empirical applications. The most influential contribution is Pedroni [47] [48] who develops several panel cointegration tests based on the residuals of the estimated regressions. ${ }^{19} \mathrm{~A}$ weakness of this type of test is its dependence on a common factor restriction: long-run cointegrating vectors (with variables in levels) are supposed to equal the short-run adjustment parameters (for variables in differences). As a consequence, a number of studies, e.g. [25], fail to reject the null hypothesis of nocointegration even in cases where it is predicted by economic theory. The explanation is that these tests lose significant power when the common factor assumption is violated [34]. For these reasons, Westerlund [61] suggests four additional cointegration tests that explicitly relax this assumption by focusing on short-run dynamics. ${ }^{20}$ Starting from

\footnotetext{
${ }^{18}$ An alternative would be to use "second generation" panel unit root tests which relax the assumption of cross-sectional dependence, e.g. Chang [9] or Pesaran [50].

${ }^{19}$ Notable contributions to the literature are Kao [29] and Westerlund [60].

20 The test is implemented using a STATA code provided by [49].
} 
an error-correction representation of the data generating process, the coefficient of the error-correction term is used to test the null hypothesis of no-cointegration:

$$
\Delta y_{i t}=\delta_{i}^{\prime} d_{t}+\alpha_{i}\left(y_{i, t-1}-\beta^{\prime} x_{i, t-1}\right)+\sum_{j=1}^{p_{i}} \alpha_{i j} \Delta y_{i, t-j}+\sum_{j=-q_{i}}^{p_{i}} \gamma_{i j} \Delta x_{i, t-j}+\varepsilon_{i t} .
$$

Error-correction in this setup occurs if $\alpha_{i}<0$, and therefore $x_{i t}$ and $y_{i t}$ are cointegrated. Accordingly, cointegration does not exist if $\alpha_{i}=0$, which implies the corresponding specification of the null hypothesis (of no-cointegration).

Concerning the alternative hypothesis, two different kinds of statements are possible: one assumes that $\alpha_{i}=\alpha<0$ for all $i$, or $\alpha_{i}<0$ for at least one $i$. The first type of test is termed panel tests and the second group-mean tests. We choose one test out of each group to test for the existence of a cointegrating relationship between productivity and knowledge spillovers. As Westerlund [61] shows by means of Monte Carlo simulations, these tests outperform both their counterparts and Pedroni-style tests in terms of power even in the presence of cross-sectional dependence.

Table 5 displays the tests where the null of no-cointegration is firmly rejected by the panel-type test at the $1 \%$ significance level. The group-mean test also mostly rejects the null, especially when controlling for a deterministic trend in the cointegrating relationship. Evidence for cointegration is strongest for the specification including domestic intra- and inter-sectoral spillover sources and international intra-sectoral knowledge, weighted by technological proximity, which is the preferred specification in our estimations. Taken together, we find evidence for the existence of a long-run relationship between productivity and international knowledge spillovers. 
Table 5

Panel cointegration tests (1985-2004)

\begin{tabular}{lcccc}
\hline Variable & \multicolumn{2}{c}{ Panel test } & \multicolumn{2}{c}{ Group-mean test } \\
& No trend & Time trend & No trend & Time trend \\
\hline $\ln (\mathrm{TFP}), \ln \left(\mathrm{S}_{\mathrm{j}}^{\mathrm{D}}\right), \ln \left(\mathrm{S}_{\mathrm{j}}^{\mathrm{F}}\right)$ & $-9.901^{* * *}$ & $-10.495^{* * *}$ & -1.365 & $-11.795^{* * *}$ \\
$\ln (\mathrm{TFP}), \ln \left(\mathrm{S}_{\mathrm{j}}^{\mathrm{D}}\right), \ln \left(\mathrm{S}_{\mathrm{j}}^{\mathrm{Fprox}}\right)$ & $-10.441^{* * *}$ & $-35.841^{* * *}$ & 2.171 & $-7.493^{* * *}$ \\
$\ln (\mathrm{TFP}), \ln \left(\mathrm{S}_{\mathrm{j}}^{\mathrm{D}}\right), \ln \left(\mathrm{S}_{-\mathrm{j}}^{\mathrm{D}}\right)$ & 2.467 & $-5.647^{* * *}$ & 5.081 & $-8.897^{* * *}$ \\
$\ln (\mathrm{TFP}), \ln \left(\mathrm{S}_{\mathrm{j}}^{\mathrm{D}}\right), \ln \left(\mathrm{S}_{-\mathrm{j}}^{\mathrm{D}}\right), \ln \left(\mathrm{S}_{\mathrm{j}}^{\mathrm{Fprox}}\right)$ & $-4.253^{* * *}$ & $-4.703^{* * *}$ & $-2.006^{* *}$ & $-10.938^{* * *}$ \\
$\ln (\mathrm{TFP}), \ln \left(\mathrm{S}_{\mathrm{j}}^{\mathrm{D}}\right), \ln \left(\mathrm{S}_{-\mathrm{j}}^{\mathrm{D}}\right), \ln \left(\mathrm{S}_{\mathrm{j}}^{\mathrm{F}}\right)$ & $-25.715^{* * *}$ & $-43.727^{* * *}$ & 2.421 & $-4.505^{* * *}$ \\
$\ln (\mathrm{TFP}), \ln \left(\mathrm{S}_{\mathrm{j}}^{\mathrm{D}}\right), \ln \left(\mathrm{S}_{\mathrm{j}}^{\mathrm{Fprox}}\right), \ln \left(\mathrm{S}_{-\mathrm{j}}^{\mathrm{Fprox}}\right)$ & $-3.961^{* * *}$ & $-4.763^{* * *}$ & $-1.479^{* *}$ & $-10.817^{* * *}$ \\
$\ln (\mathrm{TFP}), \ln \left(\mathrm{S}_{\mathrm{j}}^{\mathrm{D}}\right), \ln \left(\mathrm{S}_{-\mathrm{j}}^{\mathrm{D}}\right), \ln \left(\mathrm{S}_{\mathrm{j}}^{\mathrm{F}}\right)$, & $-6.835^{* * *}$ & -18.762 & $-4.721^{* * *}$ & $-3.448^{* * *}$ \\
$\ln \left(\mathrm{S}_{-\mathrm{j}}^{\mathrm{F}}\right)$ & & & & \\
$\ln (\mathrm{TFP}), \ln \left(\mathrm{S}_{\mathrm{j}}^{\mathrm{D}}\right), \ln \left(\mathrm{S}_{-\mathrm{j}}^{\mathrm{D}}\right), \ln \left(\mathrm{S}_{\mathrm{j}}^{\mathrm{Fprox}}\right)$, & $-5.245^{* * *}$ & $-1.742^{* *}$ & 0.977 & $-7.051^{* * *}$ \\
$\ln \left(\mathrm{S}_{-\mathrm{j}}^{\mathrm{F} p r o x}\right)$ & & & & \\
\hline
\end{tabular}

Notes: Error-correction-based cointegration test developed by Westerlund [61]. The null hypothesis is absence of cointegration. Significance levels of $10 \%, 5 \%$, and $1 \%$ for the one-tailed test are indicated by ${ }^{*}, * *$ and ${ }^{* * *}$. Lags are specified such that the Akaike information criterion is minimized.

\subsection{Estimation Results}

Having shown that the regressions will not be spurious, we now turn to the estimations. The two econometric methods applied to estimate the effect of knowledge spillovers are ordinary least squares (OLS) and dynamic ordinary least squares (DOLS). In case of cointegration, the standard OLS estimator is "super consistent", i.e. estimated coefficients converge faster to the true value. Table 6 presents panel estimations with stepwise expanding specifications derived by means of OLS. Starting with the impact of domestic spillovers, we find a significant influence of both intra- and inter-industry spillovers (Model 1). Model 2 shows the alternative where we begin by focusing on the sectoral perspective and therefore only include national and international industryspecific knowledge stocks. Again a clear impact is observed for both spillover channels. Evidently, concentrating exclusively on either the sectoral or the national perspective is misleading, since both specifications seem to suffer from omitted variable bias. As a consequence, Model 3 encompasses both perspectives. Here we find that existing 
domestic knowledge is no longer significant when allowing for international spillovers within the industry. The coefficients of domestic and international sectoral channels remain robust and comparable in size relative to Model 2 .

So far, we have used foreign knowledge stocks adjusted for technological bilateral distance since the emphasis of our analysis is on direct knowledge and not on rent spillovers. Wanting to know the sensitivity of the results to a change in the weighting pattern, we reestimate Model 3 with the unweighted sector-specific knowledge stocks $S_{j}^{F}$. The only difference occurring is the slight decrease in coefficient size of the respective variable, while domestic knowledge remains fairly stable. So far, knowledge from other countries within the same sector has a substantially larger impact on TFP than technological development in the national arena. To check whether international spillovers from other sectors also affect productivity, we include them together with national and international intra-sectoral knowledge (Model 5) and then in the full model specification (Model 6) as derived in Section 2. Again, domestic industry-specific spillovers are robust to these changes. International flows originating outside the industry turn out to be insignificant. The picture is slightly different for international intra-sectoral spillover sources: the corresponding coefficient only remains significant at the $10 \%$ level even though it increases substantially in magnitude. Its nonsignificance could be caused by the problem of collinearity. As Griliches [20] notes, estimations on international spillovers are often hampered by this type of obstacle, because the different series are usually closely related. This problem is frequently discussed in the empirical literature when assessing spillover channels on both the country-wide- and sector-levels (e.g. [41]). In our dataset, the correlation coefficient is highest - almost 0.9 - for the two foreign knowledge stocks whether or not we use the weighted or the unweighted type. Nevertheless, Lee [37] argues that since no clear criterion for determining the presence of collinearity exists, even correlations above 0.8 do not cause serious problems in this context. 


\section{Table 6}

Estimation results OLS

\begin{tabular}{lllllll}
\hline & Model 1: & Model 2: & Model 3: & Model 4: & Model 5: & Model 6: \\
\hline $\ln \left(S_{\mathrm{j}}^{\mathrm{D}}\right)$ & $0.108^{* * *}$ & $0.080^{* * *}$ & $0.081^{* * *}$ & $0.084^{* * *}$ & $0.082^{* * *}$ & $0.082^{* * *}$ \\
& $(0.019)$ & $(0.015)$ & $(0.020)$ & $(0.020)$ & $(0.014)$ & $(0.014)$ \\
$\ln \left(S_{-\mathrm{j}}^{\mathrm{D}}\right)$ & $0.047^{* * *}$ & & -0.002 & 0.014 & & 0.014 \\
& $(0.017)$ & & $(0.020)$ & $(0.019)$ & & $(0.026)$ \\
$\ln \left(\mathrm{S}_{\mathrm{j}}^{\mathrm{Fprox}}\right)$ & & $0.138^{* * *}$ & $0.139^{* * *}$ & & $0.221^{*}$ & $0.228^{*}$ \\
& & $(0.020)$ & $(0.023)$ & & $(0.131)$ & $(0.140)$ \\
$\ln \left(\mathrm{S}_{\mathrm{j}}^{\mathrm{F}}\right)$ & & & & $0.114^{* * *}$ & & \\
& & & & $(0.020)$ & & \\
$\ln \left(\mathrm{S}_{-\mathrm{j}}^{\mathrm{F} \text { prox }}\right)$ & & & & & -0.082 & -0.099 \\
& & & & & $(0.137)$ & $(0.157)$ \\
Number of groups & 181 & 181 & 181 & 181 & & 181 \\
Observations & 3620 & 3620 & 3620 & 3620 & & 3620 \\
\hline
\end{tabular}

Notes: 1. Dependent variable: $\ln (\mathrm{TFP}), 1985-2004$.

2. Robust standard errors are given in parentheses below the coefficient estimates.

$3 . * * *, * *$, and $*$ denote significance at the $1 \%, 5 \%$, and $10 \%$ level, respectively.

4. All estimated models include unreported country-level fixed effects.

Even though OLS estimates are "super consistent" in the presence of cointegration, a shortcoming is their non-normal distribution due to the finite sample bias which arises in the cases of endogeneity of regressors or serial correlation in the error terms. Therefore, the usual t-statistics could be misleading. Chen et al. [10] compare the finite sample properties of OLS with its bias-corrected counterpart and fail to reveal substantial improvements. More promising alternatives are the fully modified OLS (FMOLS) (e.g [48], [51]) and the DOLS estimator (e.g. [53], [55]). Kao and Chiang [31] study the asymptotic distributions of OLS, FMOL and DOLS and conduct Monte Carlo simulations to compare the finite sample properties. Their results illustrate that FMOLS does not outperform OLS and that DOLS is superior to both OLS and FMOLS in terms of bias reduction.

Even though the DOLS estimator shares the limiting distribution of the FMOLS estimator, the obtained coefficients may vary remarkably. To avoid the bias of OLS, the DOLS estimator expands an OLS approach by lead and lag terms of first differences of 
the explanatory variables to control for endogeneity. ${ }^{21}$ As Kao and Chiang [31] show, the estimated coefficients of DOLS depend on the chosen number of leads and lags. We follow the suggestion of Kao et al. [30] by including two lags and one lead of first differenced explanatory variables.

Table 7 presents the coefficient estimates of DOLS. With respect to statistical significance, the results corroborate our findings from the OLS estimations. ${ }^{22}$ Comparing the size of the coefficients of Model 3 for OLS and DOLS, we observe that DOLS delivers a higher elasticity of the industry-specific international knowledge spillovers at the expense of a slightly lower effect of domestic stocks. While the estimated coefficient of $\ln \left(S_{j}^{\text {Fprox }}\right)$ is 0.139 for OLS, it increases to 0.157 for DOLS.

Overall, we find an effect of $\ln \left(S_{j}^{F p r o x}\right)$ nearly twice as large as the domestic one in the DOLS estimations. The elasticity of foreign knowledge originating within the industry remains surprisingly stable $(0.154)$ when replacing the technology proximity weighted stock by the unweighted one (Model 4). We therefore do not observe a substantial effect of the weighting scheme in our analysis, possibly due to the fact that technological distance is a bilateral concept, varying only over countries but not over industries. Estimating the full model again confirms the importance of local knowledge with an elasticity of TFP of 0.07. As in all specifications including international spillovers, we never find evidence for a linkage between TFP and domestic inter-sectoral spillovers. The inclusion of both international spillover stocks leads to insignificant coefficients, but as already discussed, the issue of collinearity might influence the results for this certain specification. Therefore, Model 3 becomes our preferred specification.

\footnotetext{
${ }^{21}$ Serial correlation is accounted for in the calculation of standard errors.

22 Models 1 and 2 are provided to re-emphasize the importance of covering sectoral and international spillover sources.
} 
Table 7

Estimation results DOLS

\begin{tabular}{llllll}
\hline & Model 1 & Model 2 & Model 3 & Model 4 & Model 5 \\
\hline $\ln \left(S_{\mathrm{j}}^{\mathrm{D}}\right)$ & $0.104^{* * *}$ & $0.082^{* * *}$ & $0.074^{* * *}$ & $0.081^{* * *}$ & $0.071^{* * *}$ \\
& $(0.022)$ & $(0.018)$ & $(0.022)$ & $(0.022)$ & $(0.025)$ \\
$\ln \left(\mathrm{S}_{-\mathrm{j}}^{\mathrm{D}}\right)$ & $0.038^{*}$ & & 0.011 & 0.012 & -0.014 \\
& $(0.021)$ & & $(0.027)$ & $(0.023)$ & $(0.042)$ \\
$\ln \left(\mathrm{S}_{\mathrm{j}}^{\mathrm{Fprox}}\right)$ & & $0.152^{* * *}$ & $0.157^{* * *}$ & & 0.192 \\
& & $(0.025)$ & $(0.026)$ & & $(0.168)$ \\
$\ln \left(\mathrm{S}_{\mathrm{j}}^{\mathrm{F}}\right)$ & & & & $0.154^{* * *}$ & \\
& & & & $(0.025)$ & \\
$\ln \left(\mathrm{S}_{-\mathrm{j}}^{\mathrm{F} \text { prox }}\right)$ & & & & & -0.033 \\
& & & & & $0.191)$ \\
Number of groups & 181 & 181 & 181 & 181 & 181 \\
Observations & 3258 & 3258 & 3258 & 3258 & 3258 \\
\hline
\end{tabular}

Notes: 1. Dependent variable: $\ln (\mathrm{TFP}), 1985-2004$.

2. Robust standard errors are given in parentheses below the coefficient estimates.

$3 . * *, * *$, and $*$ denote significance at the $1 \%, 5 \%$, and $10 \%$ level, respectively.

4. All estimated models include unreported country-level fixed effects.

5. For the DOLS estimation, two lags and one lead of first differenced independent variables are included.

Our findings are in line with the empirical literature when stressing the importance of international knowledge spillovers. Initially, Coe and Helpman [12] provided evidence on the role of international $R \& D$ for enhancing productivity growth. Subsequent studies cast doubt on the results by raising methodological concerns, e.g., Kao et al. [30] reject the effect of foreign R\&D to TFP by using panel cointegration techniques while Edmond [17] claims the relationship is unstable across alternative specifications.

We address the sector specificity of knowledge by distinguishing between inter- and intra-sectoral channels. Thereby, we are able to show that foreign knowledge is conducive to TFP growth, but only within industries and it may explain why the country-level evidence is mixed. Previous studies on $R \& D$ spillovers at the industry level also corroborate our finding that foreign knowledge spurs productivity (e.g. [41], [18]). Numerically, even though we adopt a different measurement approach by relying on patent data together with technological proximity to focus on pure knowledge spillovers, our elasticities of TFP concerning intra-sectoral spillovers take a similar 
direction: Frantzen [18] reports a value of 0.095 for domestic and 0.079 for international R\&D stocks. Even though our results are of course not directly comparable, the domestic effect is surprisingly close, but our influence of knowledge originating from other countries is substantially higher. With Braconier and Sjöholm [6], we share the result of non-significance of knowledge within the country being generated in other sectors.

\section{Conclusion}

The theoretical and empirical literature suggests that knowledge transcending national boundaries contributes positively to productivity growth in other regions. Until recently, however, few studies focused on differences in technology transfer across sectors. The purpose of this paper was to assess the importance of different channels of spillovers at the industry level by distinguishing between domestic and international intra- and inter-sectoral technological externalities, clearly focusing on pure knowledge spillovers. Using patent data as a measure of innovative output to capture generated knowledge, we estimate the contribution of existing knowledge to industrial productivity. To account for technological distance between countries, we weight foreign knowledge by bilateral technological proximity.

The analysis is based on 14 OECD countries and 13 industries between 1985 and 2004 . By adopting estimation methods reflecting recent developments in the treatment of non-stationary panel data econometrics, we find that industry-specific knowledge, both nationally and internationally, mainly drives productivity in the respective sector. By contrast, knowledge flows from other sectors of the economy prove to be ineffective channels for knowledge transmission. Cross-border flows from other countries and sectors also turn out to have no productivity-enhancing effect.

Our results confirm the notion that the international flow of ideas is an influential factor for productivity growth. However, the investigation of the different channels of spillovers shows that policies designed to enhance the flow of knowledge must be targeted to the industry level. Based on our results, we suggest that policies accounting for sector-specific differences will be more beneficial for stimulating technological 
innovation and increasing productivity - the two important challenges posed by the Lisbon Agenda for the European Union. 


\section{References}

[1] P. Aghion and P. Howitt, A model of growth through creative destruction, Econometrica 60, 323-351 (1992).

[2] N. Apergis, C. Economidou and I. Filippidis, International technology spillovers, human capital and productivity linkages: Evidence from the industrial sector, Empirica 36, 365-387 (2009).

[3] K.J. Arrow, The economic implications of learning by doing, Review of Economic Studies 29, 155-173 (1962).

[4] A. Banerjee, Panel data unit roots and cointegration: An overview, Oxford Bulletin of Economics and Statistics 61, 607-629 (1999).

[5] J.I. Bernstein and M.I. Nadiri, Product demand, cost of production, spillovers, and the social rate of return to R\&D, NBER Working Paper 3625 (1991).

[6] H. Braconier and F. Sjöholm, National and international spillovers from R\&D: Comparing a neoclassical and an endogenous growth approach, Weltwirtschaftliches Archiv 143, 639-663 (1998).

[7] J. Breitung, The local power of some unit root tests for panel data, B. Baltagi (Ed.): Advances in Econometrics: Nonstationary panels, panel cointegration and dynamic panels, Vol. 15, Emerald Publishing: London, 179-222 (2000).

[8] J. Breitung and M.H. Pesaran, Unit roots and cointegration in panels, - L. Matyas, and P. Sevestre (Eds.): The Econometrics of Panel Data, Springer: Berlin and Heidelberg, 279-322 (2008).

[9] Y. Chang, Nonlinear IV unit root tests in panels with cross-sectional dependency, Journal of Econometrics 110, 261-292 (2002).

[10] B. Chen, S. McCoskey and C. Kao, Estimation and inference of a cointegrated regression in panel data: A Monte Carlo study, American Journal of Mathematical and Management Sciences 19, 75-114 (1999).

[11] M. Cincera and B. Van Pottelsberghe de la Potterie, International R\&D spillovers: A survey, Brussels Economic Review 169, 3-32 (2001).

[12] D.T. Coe and E. Helpman, International R\&D spillovers, European Economic Review 39, 859-887 (1995).

[13] D.T. Coe, E. Helpman and A.W. Hoffmaister, International R\&D spillovers and institutions, European Economic Review 53, 723-741 (2009). 
[14] T. Del Barrio-Castro, E. Lopez-Bazo and E. Serrano-Domingo, New evidence on international R\&D spillovers, human capital and productivity in the OECD, Economics Letters 77, 41-45 (2002).

[15] G. Dosi, Sources, procedures and microeconomic effects of innovation, Journal of Economic Literature 26, 1120-1126 (1988).

[16] J. Eaton and S. Kortum, International patenting and technology diffusion: Theory and measurement, International Economic Review 40, 537-570 (1999).

[17] C. Edmond, Some panel cointegration models of international R\&D spillovers, Journal of Macroeconomics 23, 241-260 (2001).

[18] D. Frantzen, Cross-sector and coss-country technology spillovers and the evolution of manufacturing productivity: A panel data analysis, Économie Appliquée 55, 31-62 (2002).

[19] C.W.J. Granger and P. Newbold, Spurious regression in econometrics, Journal of Econometrics 2, 111-120 (1974).

[20] Z. Griliches, Issues in assessing the contribution of research and development to productivity growth, Bell Journal of Economics 10, 92-116 (1979).

[21] Z. Griliches, The search for R\&D spillovers, Scandinavian Journal of Economics 94, 29-47 (1992).

[22] D. Guellec and B. Van Pottelsberghe de la Potterie, R\&D and productivity growth: Panel data analysis of 16 OECD countries, OECD Economic Studies 33, 103-126 (2001).

[23] D. Guellec, and B. Van Pottelsberghe de la Potterie, From R\&D to productivity growth: Do the institutional settings and the source of funds of R\&D matter?, Oxford Bulletin of Economics and Statistics 66, 353-378 (2004).

[24] K. Hadri, Testing for stationarity in heterogenous panel data, Econometrics Journal 3, 148-161 (2000).

[25] T. Ho, A panel cointegration approach to the saving-investment correlation, Empirical Economics 27, 91-100 (2002).

[26] K. Im, M.H. Pesaran and Y. Shin, Testing for unit roots in heterogeneous panels, Journal of Econometrics 115, 53-74 (2003).

[27] A. Jaffe, Technological opportunity and spillovers of R\&D: Evidence from firms' patents, profits, and market value, American Economic Review 76, 984-1001 (1986).

[28] A. Jaffe, Demand and supply influences in R\&D intensity and productivity growth, Review of Economics and Statistics 70, 431-437 (1988). 
[29] C. Kao, Spurious regression and residual-based test for cointegration in panel data, Journal of Econometrics 90, 1-44 (1999).

[30] C. Kao, M.H. Chiang and B. Chen, International R\&D spillovers: An application of estimation and inference in panel cointegration, Oxford Bulletin of Economics and Statistics 61, 691-709 (1999).

[31] C. Kao and M.H. Chiang, On the estimation and inference of a cointegrated regression in panel data, in B. Baltagi (Ed.): Advances in Econometrics: Nonstationary panels, panel cointegration and dynamic panels, Vol. 15, Emerald Publishing: London, 179-222 (2000).

[32] W. Keller, Trade and the transmission of technology, Journal of Economic Growth 7, 5-24 (2002).

[33] W. Keller, International technology diffusion, Journal of Economic Literature 42, 752-782 (2004).

[34] J. Kremers, N. Ericsson and J. Dolado, The power of cointegration tests, Oxford Bulletin of Economics and Statistics 54, 325-348 (1992).

[35] S. Lach, Patents and productivity growth at the industry level: A first look, Economics Letters 49, 101-108 (1995).

[36] G. Lee, Direct versus indirect R\&D spillovers, Information Economics and Policy 17, 334-348 (2005).

[37] G. Lee, The effectiveness of international knowledge spillover channels, European Economic Review 50, 2075-2088 (2006).

[38] G. Lee, International knowledge spillovers through the import of information technology commodities, Applied Economics 41, 3161-3169 (2009).

[39] A. Levin, C.F. Lin and C.S.J. Chu, Unit root tests in panel data: Asymptotic and finite sample properties, Journal of Econometrics 108, 1-24 (2002).

[40] F. Lichtenberg and B. Van Pottelsberghe de la Potterie, International R\&D spillovers: A comment, European Economic Review 42, 1483-1491 (1998).

[41] C. López-Pueyo, S. Barcenilla-Visús and J. Sanaú, International R\&D spillovers and manufacturing productivity: A panel data analysis, Structural Change and Economic Dynamics 19, 152-172 (2008).

[42] B. Los and B. Verspagen, R\&D spillovers and productivity: Evidence from U.S. manufacturing microdata, Empirical Economics 25, 127-148 (2000).

[43] J.B. Madsen, Economic growth, TFP convergence and the world export of ideas: A century of evidence, Scandinavian Journal of Economics 110, 145-167 (2008). 
[44] P. Mohnen, R\&D externalities and productivity growth, STI Review 18, 39-66 (1996).

[45] P. Mohnen, International R\&D spillovers and economic growth, in: M. Pohjola (Ed.): Information technology productivity and economic grow: International Evidence and implications for economic Development, Oxford: Oxford University Press, 50-71 (2001).

[46] M. O'Mahony and M. Timmer, Output, input and productivity measures at the industry level: The EU KLEMS database, Economic Journal 119, F374-F403 (2009).

[47] P. Pedroni, Critical values for cointegration tests in heterogeneous panels with multiple regressors, Oxford Bulletin of Economics and Statistics 61, 653-670 (1999).

[48] P. Pedroni, Panel cointegration: Asymptotic and finite sample properties of pooled time series tests with an application to the PPP hypothesis, Econometric Theory 20, 597-625 (2004).

[49] D. Persyn and J. Westerlund, Error-correction-based cointegration tests for panel data, Stata Journal 8, 232-241 (2008).

[50] M.H. Pesaran, A simple unit root test in the presence of cross-section dependence, Journal of Applied Econometrics 22, 265-312 (2007).

[51] P.C.B. Phillips and H.R. Moon, Linear regression limit theory for nonstationary panel data, Econometrica 67, 1057-1111 (1999).

[52] P.M. Romer, Endogenous technological change, Journal of Political Economy 94, S71-S102 (1990).

[53] P. Saikkonen, Asymptotically efficient estimation of cointegrating regressions, Econometric Theory 58, 1-21 (1991).

[54] U. Schmoch, F., Laville, P. Patel and R. Frietsch, Linking technology areas to industrial sectors, Final report to the European Commission, Karlsruhe: ISI (2003).

[55] J. Stock and M. Watson, A simple estimator of cointegration vectors in higher order integrated systems, Econometrica 61, 783-820 (1993).

[56] M. Timmer, M. O'Mahony and B. Van Ark, EU KLEMS growth and productivity accounts: An overview, University of Groningen and University of Birmingham, mimeo (2007).

[57] M. Timmer, T. Van Moergastel, E. Stuivenwold, G. Ypma, M. O'Mahony and M. Kangasniemi, EU KLEMS growth and productivity accounts - Part I methodology, University of Groningen and University of Birmingham, mimeo (2007). 
[58] B. Van Ark, M. O'Mahony and M. Timmer, The productivity gap between Europe and the United States: Trends and causes, Journal of Economic Perspectives 22, 25-44 (2008).

[59] B. Verspagen, Estimating international technology spillovers using technology flow matrices, Weltwirtschaftliches Archiv 133, 226-248 (1997).

[60] J. Westerlund, New simple tests for panel cointegration, Econometric Reviews 24, 297-316 (2005).

[61] J. Westerlund, Testing for error correction in panel data, Oxford Bulletin of Economics and Statistics 69, 709-748 (2007). 


\section{Appendix A}

Table A.1

Concordance assigning IPC classes to European NACE23

NACE ${ }^{24}$ (Rev.1) Industry description IPC Classes

\begin{tabular}{|c|c|c|}
\hline $15 \mathrm{t} 16$ & $\begin{array}{l}\text { Food products, } \\
\text { beverages, and tobacco }\end{array}$ & $\begin{array}{l}\text { A01H, A21D, A23B, A23C, A23D, } \\
\text { A23F, A23G, A23J, A23K, A23L, A23P, } \\
\text { C12C, C12F, C12G, C12H, C12J, C13F, } \\
\text { C13J, C13K, A24B, A24D, A24F }\end{array}$ \\
\hline $17 \mathrm{t} 19$ & $\begin{array}{l}\text { Textiles, textile } \\
\text { products, leather, and } \\
\text { footwear }\end{array}$ & $\begin{array}{l}\text { D04D, D04G, D04H, D06C, D06J, } \\
\text { D06M, D06N, D06P, D06Q, A41B, } \\
\text { A41C, A41D, A41F, A43B, A43C, B68B, } \\
\text { B68C }\end{array}$ \\
\hline 20 & $\begin{array}{l}\text { Wood, products of } \\
\text { wood and cork }\end{array}$ & B27D, B27H, B27M, B27N, E04G \\
\hline $21 \mathrm{t} 22$ & $\begin{array}{l}\text { Pulp, paper, paper } \\
\text { products, printing, and } \\
\text { publishing }\end{array}$ & $\begin{array}{l}\text { B41M, B42D, B42F, B44F, D21C, } \\
\text { D21H, D21J }\end{array}$ \\
\hline 23 & $\begin{array}{l}\text { Coke, refined petroleum } \\
\text { products, and nuclear } \\
\text { fuel }\end{array}$ & C10G, C10L, G01V \\
\hline 24 & $\begin{array}{l}\text { Chemicals and chemical } \\
\text { products }\end{array}$ & $\begin{array}{l}\text { B01J, B09B, B09C, B29B, C01B, C01C, } \\
\text { C01D, C01, C01G, C02F, C05B, C05C, } \\
\text { C05D, C05F, C05G, C07B, C07C, C07F, } \\
\text { C07G, C08B, C08C, C08F, C08, C08J, } \\
\text { C08K, C08L, C09B, C09C, C09D, C09K, } \\
\text { C10B, C10C, C10H, C10J, C10K, C12S, } \\
\text { C25B, F17C, F17D, F25J, G21F, A01N, } \\
\text { B27K, A61K, A61P, C07D, C07H, C07J, } \\
\text { C07K, C12N, C12P, C12Q, C09F, C11D, } \\
\text { D06L, A62D, C06B, C06C, C06D, C08H, } \\
\text { C09G, C09H, C09J, C10M, C11B, C11C, } \\
\text { C14C, C23F, C23G, D01C, F42B, F42D, } \\
\text { G03C, D01F }\end{array}$ \\
\hline 25 & $\begin{array}{l}\text { Rubber and plastics } \\
\text { products }\end{array}$ & $\begin{array}{l}\text { A45C, B29C, B29D, B60C, B65D, } \\
\text { B67D, E02B, F16L, H02G }\end{array}$ \\
\hline 26 & $\begin{array}{l}\text { Other nonmetallic } \\
\text { mineral products }\end{array}$ & $\begin{array}{l}\text { B24D, B28B, B28C, B32B, C03B, C03C, } \\
\text { C04B, E04B, E04C, E04, E04F, G21B }\end{array}$ \\
\hline $27 \mathrm{t} 28$ & $\begin{array}{l}\text { Basic metals and } \\
\text { fabricated metal }\end{array}$ & $\begin{array}{l}\text { B21C, B21G, B22D, C21B, C21C, C21D, } \\
\text { C22B, C22C, C22F, C25C, C25F, C30B, }\end{array}$ \\
\hline
\end{tabular}

${ }^{23}$ Based on Schoch et al. [54].

${ }^{24}$ Nomenclature générale des activités économiques dans les Communautés européennes 
products

29

Machinery

Electrical and optical equipment
D07B, E03F, E04H, F27D, H01B, A01L, A44B, A47H, A47K, B21K, B21L, B22F, B25B, B25C, B25F, B25G, B25H, B26B, B27G, B44C, B65F, B82B, C23D, C25D, E01D, E01F, E02C, E03B, E03C, E03D, E05B, E05C, E05D, E05F, E05G, E06B, F01K, F15D, F16B, F16P, F16S, F16T, F17B, F22B, F22G, F24J, G21H B23F, F01B, F01C, F01D, F03B, F03C, F03D, F03G, F04B, F04C, F04D, F15B, F16C, F16D, F16F, F16H, F16K, F16M, F23R, A62C, B01D, B04C, B05B, B61B, B65G, B66B, B66C, B66D, B66F, C10F, C12L, F16G, F22D, F23B, F23C, F23D, F23G, F23H, F23J, F23K, F23L, F23M, F24F, F24H, F25B, F27B, F28B, F28C, F28D, F28F, F28G, G01G, H05F, A01B, A01C, A01D, A01F, A01G, A01J, A01K, A01M, B27L, B21D, B21F, B21H, B21J, B23B, B23C, B23D, B23G, B23H, B23K, B23P, B23Q, B24B, B24C, B25D, B25J, B26F, B27B, B27C, B27F, B27J, B28D, B30B, E21C, A21C, A22B, A22C, A23N, A24C, A41H, A42C, A43D, B01F, B02B, B02C, B03B, B03C, B03D, B05C, B05D, B06B, B07B, B07C, B08B, B21B, B22C, B26D, B31B, B31C, B31D, B31F, B41B, B41C, B41, B41F, B41G, B41L, B41N, B42B, B42C, B44B, B65B, B65C, B65H, B67B, B67C, B68F, C13C, C13D, C13G, C13H, C14B, C23C, D01B, D01D, D01G, D01H, D02G, D02H, D02J, D03C, D03D, D03J, D04B, D04C, D05B, D05C, D06B, D06G, D06H, D21B, D21D, D21F, D21G, E01C, E02D, E02F, E21B, E21D, E21F, F04F, F16N, F26B, H05H, B63G, F41A, F41B, F41C, F41F, F41G, F41H, F41J, F42C, G21J, A21B, A45D, A47G, A47J, A47L, B01B, D06F, E06C, F23N, F24B, F24C, F24D, F25C, F25D, H05B

B41J, B41K, B43M, G02F, G03G, G05F, G06C, G06D, G06E, G06F, G06G, G06J, G06K, G06M, G06N, G06T, G07B, G07C, G07D, G07F, G07G, G09D, G09G, G10L, G11B, H03K, H03L, H02K, H02N, H02P, H01H, H01R, H02B, H01M, F21H, F21K, F21L, F21M, F21S, F21V, H01K, B60M, B61L, F21P, 


F21Q, G08B, G08G, G10K, G21C, G21D,
H01T, H02H, H02M, H05C, B81B,
B81C, G11C, H01C, H01F, H01G, H01J,
H01L, G09B, G09C, H01P, H01Q,
H01S, H02J, H03B, H03C, H03D, H03F,
H03G, H03H, H03M, H04B, H04J,
H04K, H04L, H04M, H04Q, H05K,
G03H, H03J, H04H, H04N, H04R,
H04S, A61B, A61C, A61D, A61F, A61G,
A61H, A61J, A61L, A61M, A61N,
A62B, B01L, B04B, C12M, G01T,
G21G, G21K, H05G, F15C, G01B, G01C,
G01D, G01F, G01H, G01J, G01M,
G01N, G01R, G01S, G01W, G12B,
G01K, G01L, G05B, G08C, G02B, G02C,
G03B, G03D, G03F, G09F, G04B, G04C,
G04D, G04F, G04G
B60B, B60D, B60G, B60H, B60J, B60,
B60L, B60N, B60P, B60Q, B60R, B60S,
B60T, B62D, E01H
F01L, F01M, F01N, F01P, F02B, F02D,
F02F, F02G, F02M, F02N, F02P, F16J,
G01P, G05D, G05G, B60F, B60V, B61C,
B61D, B61F, B61G, B61H, B61J, B61K,
B62C, B62H, B62J, B62K, B62L, B62M,
B63B, B63C, B63H, B63J, B64B, B64C,
B64D, B64F, B64G, E01B, F02C, F02K,
F03H


Table A.2

Technological fields ${ }^{25}$

\begin{tabular}{llll}
\hline Number & Field & Number & Field \\
\hline 1 & Food & 23 & Agricultural machinery \\
2 & Tobacco & 24 & Machine-tools \\
3 & Textiles & 25 & Special machinery \\
4 & Wearing & 26 & Weapons \\
5 & Leather & 27 & Domestic appliances \\
6 & Wood products & 28 & Computers \\
7 & Paper & 29 & Electrical motors \\
8 & Publishing & 30 & Electrical distribution \\
9 & Petroleum & 31 & Accumulators \\
10 & Basic chemicals & 32 & Lightening \\
11 & Pesticides & 33 & Other electrical \\
12 & Paint & 34 & Electronic components \\
13 & Pharmaceuticals & 35 & Telecommunications \\
14 & Soaps & 36 & Television \\
15 & Other chemicals & 37 & Medical equipment \\
16 & Man-made fibre & 38 & Measuring instruments \\
17 & Plastic products & 39 & Industrial control \\
18 & Mineral products & 40 & Optics \\
19 & Basic metals & 41 & Watches \\
20 & Metal products & 42 & Motor vehicles \\
21 & Energy machinery & 43 & Other transport \\
22 & Non-specific machinery & 44 & Consumer goods \\
\hline
\end{tabular}

25 Based on Schmoch et al. [54]. 
Figure A.1

TFP growth, $1995=100$

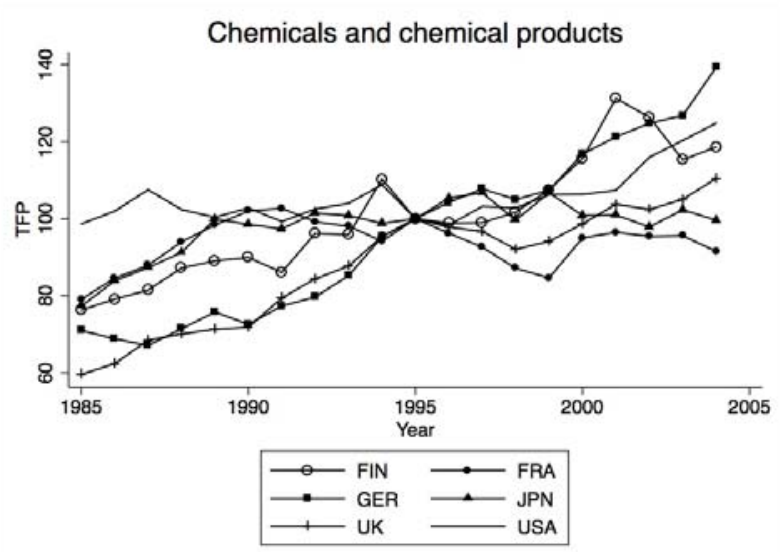

Figure A.2

TFP growth, $1995=100$

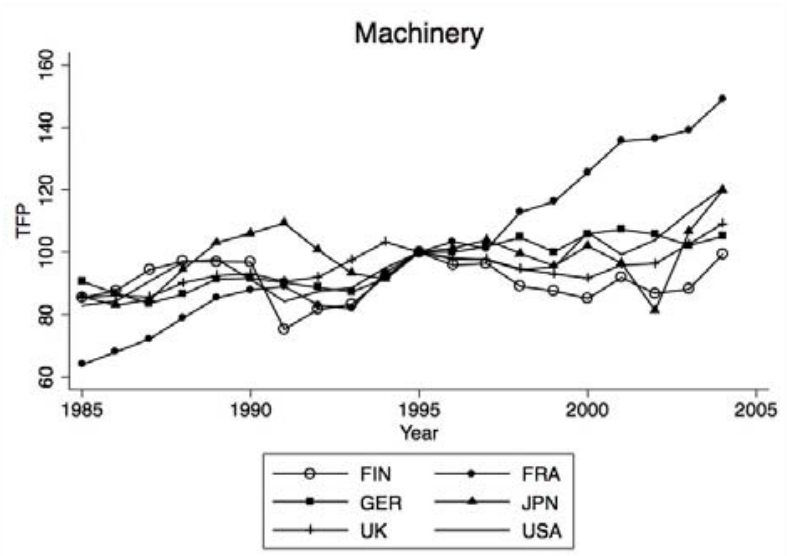

Figure A.3

TFP growth, 1995=100

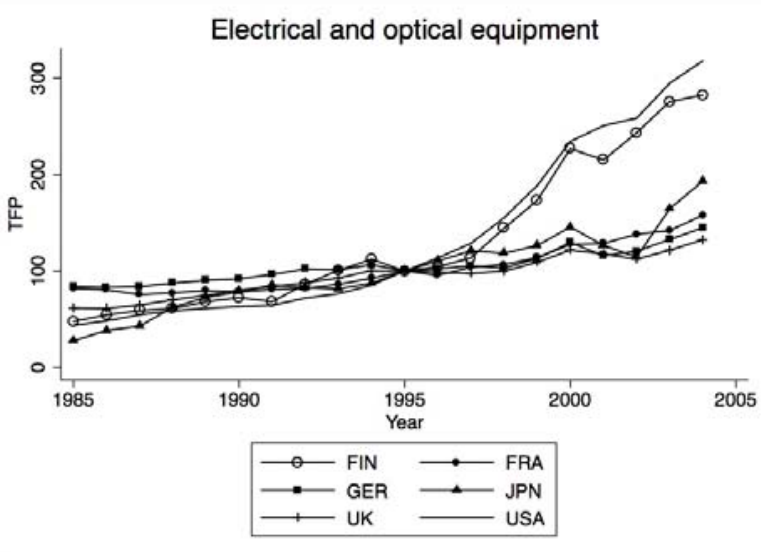

Figure A.4

TFP growth, 1995=100

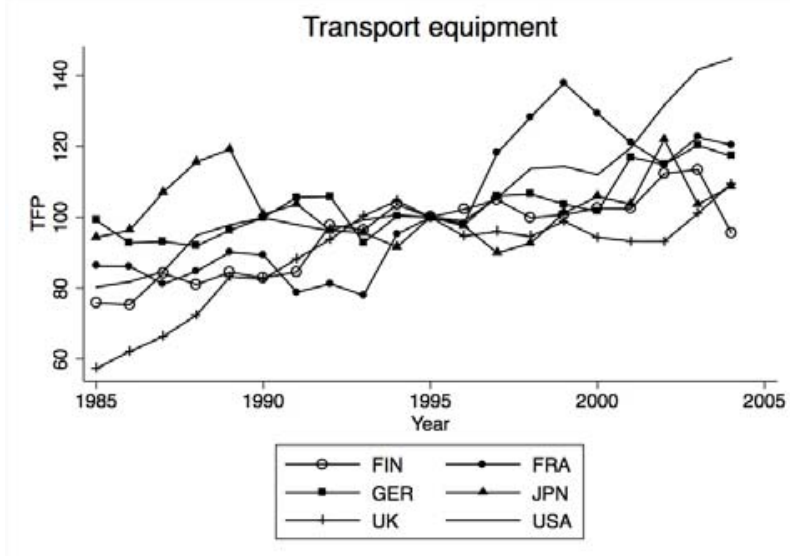


Figure A.5

Industry-specific domestic knowledge stock, 1995=100

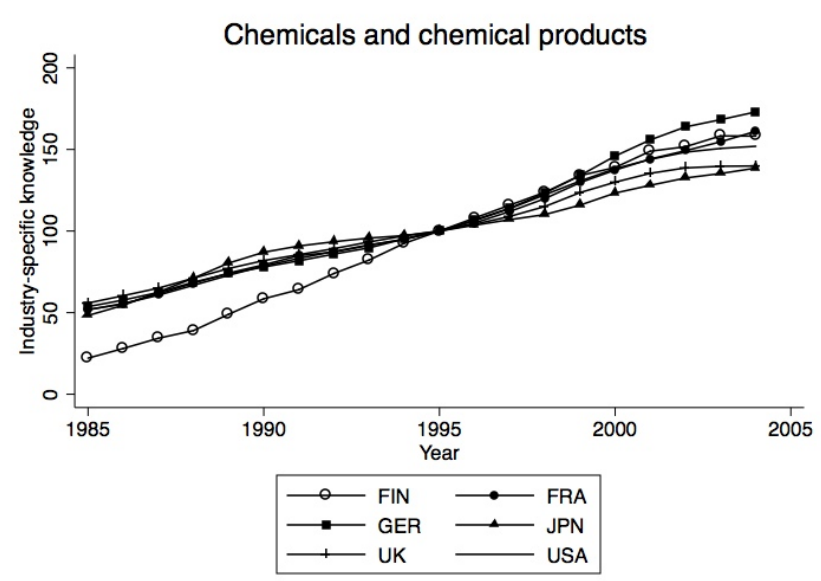

Figure A.6

Industry-specific domestic knowledge stock, 1995=100

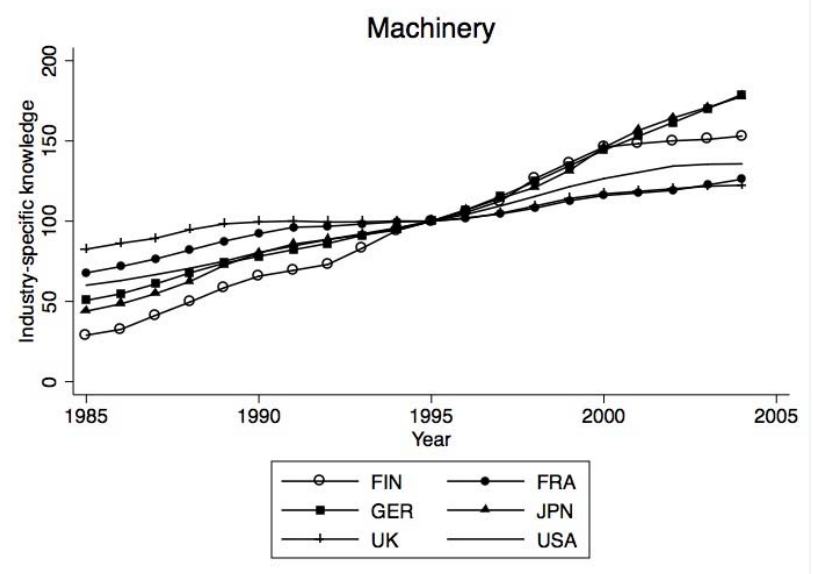

Figure A.7

Industry-specific domestic knowledge stock, 1995=100

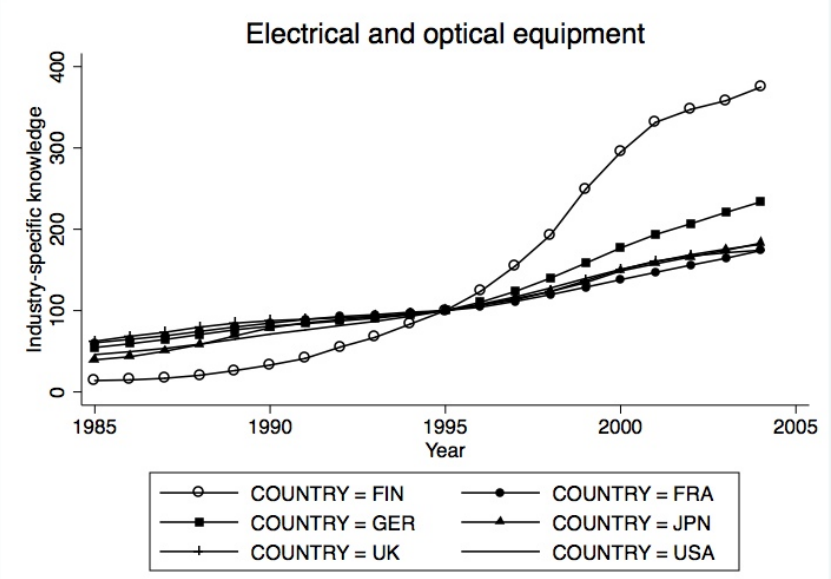

Figure A.8

Industry-specific domestic knowledge stock, 1995=100

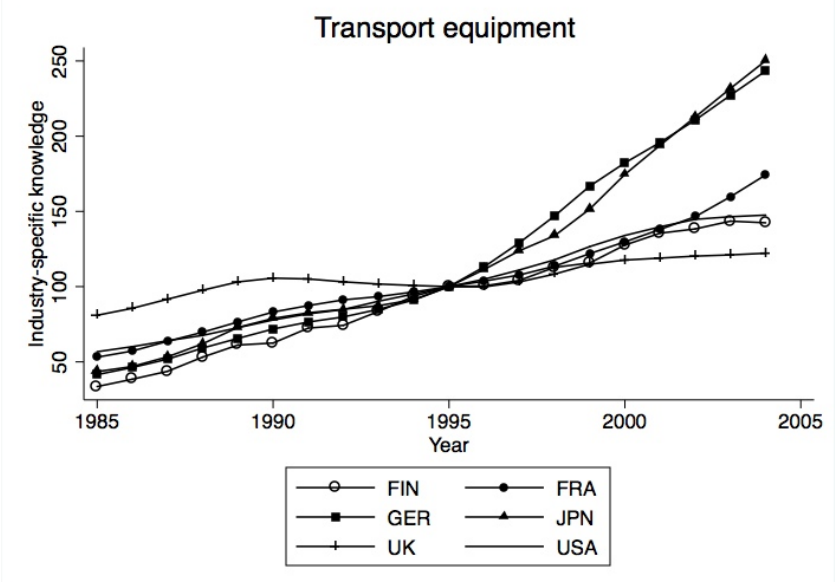

